https://helda.helsinki.fi

Upper endoscopy for non-acute non-specific symptoms is seldom beneficial for children under the age of seven

\title{
Helin, Noora
}

2020-04

Helin , N , Kolho , K-L , Rintala , R \& Merras-Salmio , L 2020 , ' Upper endoscopy for non-acute non-specific symptoms is seldom beneficial for children under the age of seven ' , Acta Paediatrica , vol. 109 , no. 4 , pp. 827-835 . https://doi.org/10.1111/apa.15027

http://hdl.handle.net/10138/319488

https://doi.org/10.1111/apa.15027

unspecified

acceptedVersion

Downloaded from Helda, University of Helsinki institutional repository.

This is an electronic reprint of the original article.

This reprint may differ from the original in pagination and typographic detail.

Please cite the original version. 
DR. NOORA HELIN (Orcid ID : 0000-0001-7240-7297)

PROF. KAIJA-LEENA KOLHO (Orcid ID : 0000-0001-9170-8415)

\section{Article type : Regular Article}

Upper endoscopy for non-acute non-specific symptoms is seldom beneficial for children under the age of seven

Noora Helin $\mathrm{MD}^{\mathrm{a}}$, Kaija-Leena Kolho MD, $\mathrm{PhD}^{\mathrm{b}}$,
Risto Rintala MD, $\mathrm{PhD}^{\mathrm{c}}$, Laura Merras-Salmio MD, $\mathrm{PhD}^{\mathrm{a}}$.

\section{Affiliations:}

a Children's Hospital, Paediatric Research Centre, University of Helsinki, Helsinki University Hospital Department of Paediatrics

b Tampere University Hospital Department of Paediatrics and University of Helsinki

c Paediatric Research Centre, University of Helsinki, Helsinki University

Hospital Department of Paediatric Surgery

This article has been accepted for publication and undergone full peer review but has not been through the copyediting, typesetting, pagination and proofreading process, which may lead to differences between this version and the Version of Record. Please cite this article as doi: 10.1111/APA.15027

This article is protected by copyright. All rights reserved 
Short title: Upper endoscopy in young children

Correspondence to: Noora Helin, Children's Hospital, Paediatric Research

Centre, Stenbäckinkatu 9, 00290 Helsinki, Finland, noora.helin@helsinki.fi, +35894711 


\section{ABSTRACT}

Aim: This study estimated the diagnostic yield of oesophagogastroduodenoscopy (OGD) in young children with non-acute, non-specific gastrointestinal or respiratory symptoms who were treated by a Finnish tertiary level referral centre.

Methods: A retrospective chart analysis was performed on 1850 Finnish children under seven years of age who underwent their first diagnostic OGDs at Helsinki University Hospital during 2006-2016. We noted the endoscopy indications, macroscopic findings, the histology of the mucosal biopsies and the follow-up data.

Results: After the exclusion criteria were applied, we enrolled 666 patients $(57.7 \%$ boys) at a median age of 3.5 years. The number of children with non-specific symptoms referred for OGD increased 2.3-fold in 11 years. A routine set of biopsies was obtained in $644 / 666(96.7 \%)$ of the endoscopies. The OGD was both macroscopically and histologically normal in $519 / 644(80.6 \%)$ of cases. The most common indication was to rule out gastro-oesophageal reflux disease in 268/666 (40.2\%) cases and the most frequent histological diagnosis was mild to moderate oesophagitis in 57/644 (8.9\%) cases. There was no erosive oesophagitis.

Conclusion: The diagnostic yield of macroscopic and histological OGD findings was low in our cohort. Unless there are alarming symptoms, younger children do not need OGD.

Key words: Biopsy; Gastritis; Gastro-oesophageal reflux; Oesophagitis; Respiratory symptoms 


\section{ABBREVIATIONS}

FGID, Functional gastrointestinal disorder; GOR, Gastro-oesophageal reflux, GORD, Gastro-oesophageal reflux disease; GI, Gastrointestinal; IQR, interquartile range; OGD, oesophagogastroduodenoscopy

\section{Key notes:}

-We estimated the diagnostic yield of the first oesophagogastroduodenoscopy (OGD) performed in 666 children under the age of seven with non-acute, non-specific gastrointestinal or respiratory symptoms.

-The number of children with non-specific symptoms referred for OGD increased 2.3-fold from 2006-2016, but the diagnostic yield of macroscopic and histological OGD findings was low in this Finnish cohort.

-Unless there are alarming symptoms, younger children do not need OGD. 


\section{INTRODUCTION}

Upper endoscopy, or oesophagogastroduodenoscopy (OGD), is a convenient tool to diagnose and treat many diseases of the gastrointestinal (GI) tract (1). However, it is not easy to select patients for this procedure because Gl symptoms are common and are poor in predicting the diagnostic yield of paediatric OGDs $(2,3)$.

In infancy, the most common functional gastrointestinal disorder (FGID) is gastro-oesophageal reflux (GOR) which is defined as the passage of gastric contents to the oesophagus and is often considered physiological (4-7). In children older than four years of age, the pain related FGIDs dominate (8-9).

Gastro-oesophageal reflux disease (GORD) is defined as a condition in which GOR provokes troublesome symptoms or complications such as oesophagitis $(6,7,10,11)$. The estimated prevalence of GORD has been shown to vary widely and increase with age (10). In studies on paediatric GORD, oesophagitis diagnosed with OGD has mainly been found in children with structural abnormalities of the gastrointestinal $(\mathrm{Gl})$ tract and in children with neurodevelopmental abnormalities $(12,13)$. The role of OGD in the diagnosis of non-acute upper GI symptoms in otherwise healthy young children is less clear $(2,14,15)$. The role of GOR or GORD in causing asthma, wheezing or cough remains unproven (16-17). The suggestion that GORD causes respiratory symptoms is not supported by the European Society of Paediatric Gastroenterology and Nutrition position paper on GOR and GORD (18). However, during the last few decades various respiratory symptoms were linked to GORD and OGD is often performed together with a bronchoscopy. 
The number of patients receiving OGD has risen rapidly in last two decades $(2,14,19,20,21)$. Interestingly, most of the paediatric OGDs performed have been reported to yield a normal result $(2,3$, $15,20,21)$. These studies have addressed the whole paediatric population, from infancy through to the teenage years and have produced variable definitions for the normal OGD. Our own clinical experience suggests that the rate of fully normal OGDs is high among infants and young children with unknown predisposing factors. However, data on OGD findings in the youngest children are scarce. Therefore, the aim of this study was to evaluate the diagnostic yield of OGD in infants and children younger than seven years of age presenting with non-acute, non-specific Gl and respiratory symptoms leading to the endoscopy. The study covered the first OGDs performed on patients from 2006-2016. 


\section{METHOD}

\section{Study participants}

We performed a retrospective chart review on all children younger than seven years of age who had undergone an OGD at Helsinki University Children's Hospital, Finland, a tertiary level referral centre, between 2006-2016. Cases were identified by using the Nordic Classification code for Surgical Procedures UJD10 for upper endoscopy. Our centre performs nearly all paediatric endoscopies in the Uusimaa region of Finland, which has a population of 1.7 million. The smaller hospitals mainly perform OGDs to diagnose antibody screening positive coeliac disease and the data from these centres were not included in this study.

We identified 2750 OGDs, but only included the first diagnostic OGD per patient and this provided 1850 cases. The medical diagnoses were listed according to the International Classification of Diseases codes version 10. We excluded patients with prediagnosed malformations of the GI tract, upper airway and head or neck area, as well as patients with short bowel syndrome, portal hypertension, known oesophageal varices or acute hematemesis and graft versus host disease. The exclusion criteria also included OGDs performed to place a gastrostomy, cases with suspected antibody screening positive coeliac disease and patients who underwent OGD to obtain Helicobacter pylori -cultures or identify a foreign body or caustic injury (Figure 1).

The final number of children with primary OGDs was 666 and they were placed in two groups. The first was non-specific non-acute gastrointestinal symptoms such as abdominal pain, vomiting, regurgitation, heartburn, dysphagia and feeding problems with failure to thrive. The second was common respiratory symptoms such as prolonged coughing, wheezing, poor response to asthma 
medication and recurrent pneumonia. We collected data on patient demographics, such as gestational age at birth, previous diagnoses and medication.

We categorised the patients as follows: $122(60.7 \%$ male) were up to one year of age, 230 (64.8\% male) were 1-2 years of age and 314 (51.3\% male) were 3-6 years of age. We used the leading symptom for analysis if several symptoms were listed.

\section{Upper endoscopy}

All OGDs were performed by paediatric surgeons and paediatric gastroenterologists under general anaesthesia, using propofol maintenance and video endoscopes that were appropriate for the patient's age and size. Biopsies were taken from the duodenum, the antrum, the corpus, and the oesophagus, even if the macroscopic appearance was normal. The biopsies were investigated by small number of paediatric pathologists who graded the level of inflammation as none, mild, moderate or severe according to the presence of inflammatory changes. The histological diagnoses were not re-assessed.

We noted the macroscopic endoscopy findings and the histological diagnoses from the obtained biopsies. If the patient also underwent a bronchoscopy or a colonoscopy, we also reviewed the histological diagnosis from those biopsies. The clinical impact of the OGD on patient's consecutive care was judged to be positive if the OGD results confirmed a new diagnosis or changed the medical treatment and, or the follow-up plan. We reviewed all the OGDrelated complications and any symptoms that led to contact with the hospital within 72 hours after the OGD. 
Each patient's medical chart was reviewed until 15 March 2018.

The Helsinki University Hospital Ethics committee approved this study (HUS/3668/2017). According to Finnish legislation, informed consent was not needed for this register-based study.

\section{Statistical methods}

Data are provided as medians and interquartile ranges (IQR) unless otherwise stated. Comparisons between the OGD findings in the age groups and between patients with or without acid blockers at the time of the OGD were analysed using Fisher's exact test. The software used was GraphPad Prism version 7.01 for Windows, (GraphPad Software, San Diego, California USA). Statistical significance was set as $p<0.05$. 


\section{RESULTS}

\section{Patients}

We identified 666 children (57.7\% male) who had undergone their first diagnostic OGD because of non-acute non-specific gastrointestinal or respiratory symptoms at less than seven years of age (Table 1). More than $90 \%$ were Caucasian and their median age was 3.5 years (IQR 1.5-5.2). The number of OGDs in our cohort increased 2.3-fold during the 11-year study period due to the increased number of patients with respiratory or reflux-related symptoms referred to an OGD (Figure 2). Of the 666 children, more than one-third $(n=267,40.1 \%$ ) had been diagnosed with a chronic condition such as asthma and, or, atopy $(n=100,15.0 \%)$, or food allergies with gastrointestinal symptoms $(n=26,3.9 \%)$. Functional gastrointestinal disorders were noted in 47 (7.6\%). Other non-GI conditions among the 666 children were congenital syndromes and non-GI malformations ( $n=75,11.3 \%$ ), epilepsy or neurologic impairment including cerebral palsy $(C P)(n=23,3.5 \%)$. Data on pregnancy and birth were available for 477 (71.6\%) of the 666 children, and 100/477 (54.0\% boys) were born prematurely before 37 weeks of gestation.

Nearly $30 \%$ of the 666 patients had at least one previous prescription of acid blockers (>95\% proton pump inhibitors) and 598 $(89.8 \%)$ of patients had a minimum of two weeks free from acid blockers prior to the OGD. Despite being advised to stop the acid blockers before the OGD, 42 (6.3\%) continued to be given them due to perceived GORD symptoms and there were no data for the other $26(3.9 \%)$.

\section{Symptoms and endoscopy indications}

The most commonly reported symptoms resulting in an OGD were reflux related, such as dysphagia, spitting up or vomiting, heartburn, 
problems with eating in 236/666 (35.4\%) cases. The number of patients with various respiratory symptoms such as wheezing, rhonchi, cough and recurrent pneumonias was 136/666 (20.4\%) and haematochezia was 115/666 (17.2\%). The three most frequent clinical indications for the OGD were suspicion or exclusion of GORD in 268/666 (40.2\%) cases, differential diagnosis of nonspecific respiratory symptoms in 120/666 $(18.0 \%)$ and inflammatory bowel disease in 107/666 (16.1\%).

\section{Endoscopy findings}

Macroscopic appearance was normal in $94.0 \%$ of subjects (Table 2). The most common macroscopic abnormality that was reported was dull oesophageal mucosa without erosions (27.5\%). Routine biopsies were taken in $96.7 \%$ of cases. The median age of 22 patients (68.2\% male) who were not biopsied was 2.8 years (IQR $0.5-5.1$ ) and the macroscopic appearance was considered normal in 20 . Of the remaining two patients, one had a suspicion of malrotation and the other had dull oesophageal mucosa. Of the patients with macroscopic abnormalities, 24/40 (60.0\%) had histological changes.

We found no significant difference in the macroscopic findings between the age groups.

The most frequent histological diagnosis was oesophagitis in $57 / 644(8.9 \%)$ cases, of which $78.9 \%$ were classified as mild and $21.1 \%$ as moderate. None had severe erosive oesophagitis. Of the cases with oesophagitis, 41/57 (71.9\%) were diagnosed with clinical GORD, which presented $6.4 \%$ of all OGDs, Tables 2, 3 and 4 . The occurrence of GORD-related histological oesophagitis increased with age: one histological oesophagitis in a patient younger than one year of age and 23 in patients aged $3-6$ years of age $(p=0.017)$. 
One-third of the children with histological reflux oesophagitis had a non-GI congenital malformation or a neurologic debilitating diagnosis. The incidence of GORD-related histological oesophagitis in children with cerebral palsy was $40.0 \%$ (4/10) and $13.0 \%$ $(13 / 100)$ in the group of children born prematurely. Only one patient with respiratory symptoms had macroscopic changes $(0.8 \%)$ and mild histological oesophagitis was found in 8/115 (7.0\%) including five patients without OGD biopsies, Table 3.

Eosinophilic oesophagitis was found in two boys $(0.3 \%)$ while oesophagitis, caused by Candida albicans-infection and gastric metaplasia in the oesophagus, were each found in one patient. (Table 4). The frequency of histological findings rose with increasing age (Table 2). The data on acid blocker use was available for all patients with histological oesophagitis and for 252/268 (94.0\%) with a suspicion of GORD. Of those with suspected GORD who continued to be given the acid blockers, $14.0 \%$ had histological oesophagitis compared with $17.7 \%$ of patients without an acid blocker $(p=0.82)$.

After oesophagitis, the second most common abnormal histological finding was gastritis in 28/644 (4.3\%) cases. Most of the gastritis cases were mild or superficial $(25 / 28,89 \%)$, and half of them were found with concurrently diagnosed inflammatory bowel disease (Tables 2, 3 and 4).

We found a few cases of duodenitis, including one severe eosinophilic enteritis (Table 4). There were no cases with villous atrophy compatible with undiagnosed coeliac disease. Likewise, there were no unexpected cases of Helicobacter pylori colonisation.

The OGD result was macroscopically and histologically normal in $519 / 644(80.6 \%)$ of the patients. The macroscopic and, or histological results only had a positive impact on the patient's 
consecutive care in 70/666 (10.5\%) patients. They included 43 children with newly diagnosed inflammatory bowel disease.

Anaesthesia and, or OGD related complications were rare. One patient, aged one year, was admitted to intensive care because of respiratory distress related to airway obstruction after extubation. We found three cases of post-operative fever and two cases of prolonged wheezing and urticaria.

The median length of follow-up was two years (IQR $0.5-5$ ) and we lost only $16 / 666$ patients (2.4\%) to follow-up. There were no clinically significant changes in patients' diagnoses during the follow-up period. 


\section{DISCUSSION}

We conducted a retrospective chart review of 666 children who were younger than seven years of age and had undergone an upper GI endoscopy -oesophagogastroduodenoscopy or OGD- to diagnose non-specific GI and, or respiratory symptoms. All had been admitted to our tertiary level children's hospital between 2006 and 2016. Our referral centre in Helsinki, Finland, is the largest in the country and serves a population of 1.7 million inhabitants, including approximately 200,000 children younger than seven years of age. Our aim was to describe the diagnostic yield of the OGD findings in this young patient group with non-specific symptom profiles.

In our study, the number of fully normal OGDs was high (80.6\%). This number was in line with those reported by the previous studies $(2,3,15,21,22,23)$ with older cohorts. In our cohort, the OGD yielded novel information in only $10.5 \%$ of cases. The macroscopic appearance was normal in nearly all patients in our cohort (94.0\%). The few macroscopic findings noted were related to the appearance of oesophageal mucosa. The prevalence of erosive oesophagitis is known to raise with age (23). Our findings were in line with this, as there were no cases of erosive oesophagitis in our cohort of children who were younger than seven years of age. The most common histological diagnosis was mild to moderate oesophagitis (8.9\%), and only $18.0 \%$ of these cases were related to non-specific macroscopic mucosal changes. We found that $70.2 \%$ of the cases with histological oesophagitis occurred in patients with clinical GORD. The significance of non-erosive histological oesophagitis in GORD is unclear (24). Non-erosive reflux oesophageal phenotypes were assessed in a study of children who were over five years of age (25), but studies addressing younger children have been under- 
powered due very small numbers of patients. Our results indicate that histological findings, suggesting a disease pathology, are rare in infants with non-specific symptoms.

In the present study, the most common indication for an OGD was the need to confirm suspected GORD or exclude it. The correlation of GOR-related symptoms and positive OGD findings in children has previously been shown to be poor $(2,3,22,23,26)$. Our results were in line with this. European Society of Paediatric Gastroenterology, Hepatology and Nutrition published a position paper on GORD in 2018 stating that OGD was not recommended for first line diagnostics. However, the paper did state that it could be used to evaluate alarming symptoms and possible complications of GORD and in differential diagnostics (18). Other guidelines are also available (19). Our data should reassure clinicians to treat reflux symptoms according to expert guidelines, as erosive oesophagitis is extremely rare in non-syndromic infants with non-specific symptoms.

The incidence of paediatric eosinophilic oesophagitis has been increasing in both North America and Europe (27), but it has only just started to rise in Finland. Our two patients with histologically confirmed eosinophilic oesophagitis had significant symptoms leading to weight loss, but the suspicion was not confirmed in those with less severe symptoms. Because we routinely biopsy even macroscopically normal mucosa, it is unlikely we would have missed cases of eosinophilic oesophagitis.

Various respiratory symptoms may cause a suspicion of GORD or structural abnormalities and OGD is often performed in addition to a bronchoscopy. The role of GORD and so-called silent GORD in 
causing respiratory symptoms or asthma has not been proven (16, 17). A review published in 2018 stated that the data suggested that GORD did not cause or result from asthma (28). In our study, respiratory symptoms were not associated with significant macroscopic or histological OGD findings.

Gastritis was rare in our patients and was found in patients diagnosed with inflammatory bowel disease. In our study, those with known positive coeliac disease serology were excluded and there were no incidental cases of villous atrophy.

Our results suggest that, in order to gain best diagnostic yield, the referral criteria for OGD must be clearly stated. The decision to perform an OGD should be based on the objective criteria in the current international recommendations $(18,19)$.

A strength of this study was the uniformity of the single centrebased data, with a large number of patients. The OGDs were performed by experienced paediatric surgeons and paediatric gastroenterologists. OGD performed under general anaesthesia was safe in this cohort, with less than $1 \%$ experiencing postoperative medical problems. This rate was smaller than the rates presented in previous studies $(29,30)$.

Nearly all patients had routine biopsies taken and the histological analyses were conducted by a small number of paediatric pathologists. Since health care in Finland is government-funded, our comprehensive cohort comprised children from all socioeconomic groups.

The limitations of this study, as in most retrospective studies, included the fact that medical charts were not always complete. Also, our study cohort was comprised almost entirely of Caucasians 
with an urban background. Although parents were advised to discontinue the use of acid blockers prior to their child having an OGD, a small number were still given the medication. This may have affected the grade of histological oesophagitis. However, those who continued to medicate their children were doing so because of ongoing perceived, severe GORD-related symptoms and therefore any erosive oesophagitis underlying these symptoms would have been noted. 


\section{CONCLUSION}

The diagnostic yield of OGD was low in our cohort of 666 infants

and young children who were younger than seven years of age and presented with non-specific, non-acute symptoms. We believe that younger children do not need OGDs unless they present with alarming symptoms.

FUNDING SOURCE: This study did not receive any specific funding.

CONFLICTS OF INTEREST: The authors have no conflicts of interest to declare. 


\section{References}

1. Friedt M, Welsch S. An update on pediatric endoscopy. Eur J Med Res. 2013 Jul 25;18:24,783X-18-24.

2. Alabd Alrazzak B, Husien T, Preston DL, Elitsur Y. Upper endoscopy in children: Do symptoms predict positive findings? Clin Pediatr (Phila). 2014 May;53(5):474-8.

3.Wang S, Younus O, Rawat D, Naik S, Giles E, Meadows N et al. Clinical Presentation and Outcomes of Diagnostic Endoscopy in Newly Presenting Children With Gastrointestinal Symptoms. J Pediatr Gastroenterol Nutr: June 2018 - Volume 66 - Issue 6 - p 876-881

4. Nelson SP, Chen EH, Syniar GM, Christoffel KK. Prevalence of symptoms of gastroesophageal reflux during childhood: A pediatric practice-based survey. pediatric practice research group. Arch Pediatr Adolesc Med. 2000 Feb;154(2):150-4.

5. Lightdale JR, Gremse DA, Section on Gastroenterology, Hepatology, and Nutrition. Gastroesophageal reflux: Management guidance for the pediatrician. Pediatrics. 2013 May;131(5):e1684-95.

6. Rybak A, Pesce M, Thapar N, Borrelli O. Gastro-esophageal reflux in children. Int J Mol Sci. 2017 Aug 1;18(8):10.3390/ijms18081671.

7. Benninga MA, Faure C, Hyman PE, St James Roberts I, Schechter NL, Nurko S. Childhood functional gastrointestinal disorders: Neonate/toddler. Gastroenterology Volume 150, Issue 6, May 2016, Pages 1443-1455.e2

8. Chitkara DK, Rawat DJ, Talley NJ. The epidemiology of childhood recurrent abdominal pain in western countries: A systematic review. Am J Gastroenterol. 2005 Aug;100(8):1868-75. 
9. Boronat AC, Ferreira-Maia AP, Matijasevich A, Wang YP. Epidemiology of functional gastrointestinal disorders in children and adolescents: A systematic review. World $\mathrm{J}$ Gastroenterol. 2017 Jun 7;23(21):3915-27.

10. Mousa H, Hassan M. Gastroesophageal reflux disease. Pediatr Clin North Am. 2017 Jun;64(3):487-505.

11. Gold BD. Review article: Epidemiology and management of gastro-oesophageal reflux in children. Aliment Pharmacol Ther. 2004 Feb;19 Suppl 1:22-7.

12. Kim S, Koh H, Lee JS. Gastroesophageal reflux in neurologically impaired children: What are the risk factors? Gut Liver. 2017 Mar 15;11(2):232-6.

13. Marseglia L, Manti S, D'Angelo G, Gitto E, Salpietro C, Centorrino A, et al. Gastroesophageal reflux and congenital gastrointestinal malformations. World $J$ Gastroenterol. 2015 Jul 28;21(28):8508-15.

14. Volonaki E, Sebire N, Borrelli O, Lindley K, Elawad M, Thapar N, et al. Gastrointestinal endoscopy and mucosal biopsy in the first year of life: indications and outcome. J.Pediatr.Gastroenterol.Nutr., 2012, 55, 1, 62-65

15. Bonilla S, Deli W, Saps M. The prognostic value of obtaining a negative endoscopy in children with functional gastrointestinal disorders. Clin Pediatr (Phila). 2011 May;50(5):396-401.

16. Sopo SM, Radzik D, Calvani M. Does treatment with proton pump inhibitors for gastroesophageal reflux disease (GERD) improve asthma symptoms in children with asthma and GERD? A systematic review. J Investig Allergol Clin Immunol. 2009;19(1):15.

17. Blake K, Teague WG. Gastroesophageal reflux disease and childhood asthma. Curr Opin Pulm Med. 2013 Jan;19(1):24-9.

18. Rosen R, Vandenplas Y, Singendonk M, Cabana M, DiLorenzo C, Gottrand F, et al. Pediatric gastroesophageal reflux clinical practice guidelines: Joint recommendations of 
the North American Society for Pediatric Gastroenterology, Hepatology, and Nutrition and the European Society for Pediatric Gastroenterology, Hepatology, and Nutrition. J Pediatr Gastroenterol Nutr. 2018 Mar;66(3):516-54.

19. Lightdale J, Acosta R, Shergill A, Chandrasekhara V, Chathadi K, Early D et al ASGE Standards of Practice Committee. Modifications in endoscopic practice for pediatric patients Gastrointest.Endosc., 2014, 79, 5, 699-710

20. Franciosi JP, Fiorino K, Ruchelli E, Shults J, Spergel J, Liacouras CA, et al. Changing indications for upper endoscopy in children during a 20-year period. J Pediatr Gastroenterol Nutr. 2010 Oct;51(4):443-7.

21. Thomson M, Sharma S. Diagnostic yield of upper and lower gastrointestinal endoscopies in children in a tertiary centre. J Pediatr Gastroenterol Nutr 2017 Jun;64(6):903-906

22. Gupta SK, Hassall E, Chiu YL, Amer F, Heyman MB. Presenting symptoms of nonerosive and erosive esophagitis in pediatric patients. Dig Dis Sci. 2006 May;51(5):858-63.

23. Gilger MA, El-Serag HB, Gold BD, Dietrich CL, Tsou V, McDuffie A, et al. Prevalence of endoscopic findings of erosive esophagitis in children: A population-based study. $J$ Pediatr Gastroenterol Nutr. 2008 Aug;47(2):141-6.

24.Gonzalez Ayerbe JI, Hauser B, Salvatore S, Vandenplas Y. Diagnosis and Management of Gastroesophageal Reflux Disease in Infants and Children: from Guidelines to Clinical Practice. Pediatr Gastroenterol Hepatol Nutr. 2019;22(2):107-121.

25. Mahoney L, Nurko S, Rosen R. The Prevalence of Rome IV Nonerosive Esophageal Phenotypes in Children. J.Pediatr., Oct 2017, vol 189, 86-91 
26.Sheiko MA, Feinstein JA, Capocelli KE, Kramer RE. Diagnostic yield of EGD in children: a retrospective single-center study of 1000 cases. Gastrointest.Endosc., 2013, $78,1,47-54 . e 1$

\section{Arias Á, Pérez-Martínez I, Tenías JM, Lucendo AJ. Systematic review with} meta-analysis: the incidence and prevalence of eosinophilic oesophagitis in children and adults in population-based studies. Aliment Pharmacol Ther, 2016,43: 3-15

28. de Benedictis FM, Bush A. Respiratory manifestations of gastro-oesophageal reflux in children. Arch Dis Child 2018;103:292-6

29. Kramer RE, Narkewicz MR. Adverse events following gastrointestinal endoscopy in children: Classifications, characterizations, and implications. J Pediatr Gastroenterol Nutr. 2016 Jun;62(6):828-33.

30. Thakkar K, El-Serag HB, Mattek N, Gilger MA. Complications of pediatric EGD: A 4year experience in PEDS-CORI. Gastrointest Endosc. 2007 Feb;65(2):213-21. 
Table 1

Background data on the study cohort of 666 paediatric patients younger than seven years of age, median age 3.5 years (IQR 1.5 -5.2), who underwent oesophagogastroduodenoscopy (OGD) because of unspecific gastrointestinal or common respiratory symptoms. Single centre data from years 2006-2016.

\begin{tabular}{|c|c|c|c|}
\hline & Age $0-1$ year & Age 1-3 years & Age 3-6 years \\
\hline Number of patients & 122 & 230 & 314 \\
\hline Gender male/ \% & $74 / 60.7 \%$ & $149 / 64.8 \%$ & $161 / 51.3 \%$ \\
\hline \multicolumn{4}{|l|}{$\begin{array}{l}\text { Indication for OGD } \\
\text { (number/\% of all in } \\
\text { each age group): }\end{array}$} \\
\hline $\begin{array}{l}\text { Suspicion of GORD } \\
n=268\end{array}$ & $38 / 31.1 \%$ & $100 / 43.5 \%$ & $130 / 41.4 \%$ \\
\hline $\begin{array}{l}\text { Common respiratory } \\
\text { symptoms } n=120\end{array}$ & $41 / 33.6 \%$ & $59 / 25.7 \%$ & $20 / 6.4 \%$ \\
\hline Suspicion of IBD n=107 & $2 / 1.6 \%$ & $25 / 10.9 \%$ & $80 / 25.5 \%$ \\
\hline $\begin{array}{l}\text { Hematochezia (non- } \\
\text { IBD) } n=50\end{array}$ & $6 / 4.9 \%$ & $13 / 5.7 \%$ & $31 / 9.9 \%$ \\
\hline $\begin{array}{l}\text { Exclusion of anatomic } \\
\text { abnormality } n=33\end{array}$ & $24 / 19.7 \%$ & $4 / 1.7 \%$ & $5 / 1.6 \%$ \\
\hline Dysphagia $n=16$ & 0 & $4 / 1.7 \%$ & $12 / 3.8 \%$ \\
\hline Failure to thrive $n=15$ & $6 / 4.9 \%$ & $8 / 3.5 \%$ & $1 / 0.3 \%$ \\
\hline Anemia $n=8$ & 0 & 0 & $8 / 2.5 \%$ \\
\hline $\begin{array}{l}\text { Malabsorption/diarrhea } \\
\mathrm{n}=8\end{array}$ & $2 / 1.6 \%$ & $2 / 0.9 \%$ & $4 / 1.3 \%$ \\
\hline $\begin{array}{l}\text { Recurrent abdominal } \\
\text { pain } n=7\end{array}$ & 0 & 0 & $7 / 2.2 \%$ \\
\hline Suspicion of EoE n=7 & 0 & $3 / 1.3 \%$ & $4 / 1.3 \%$ \\
\hline $\begin{array}{l}\text { Protein-losing } \\
\text { enteropathy } n=5\end{array}$ & $3 / 2.5 \%$ & $2 / 0.9 \%$ & 0 \\
\hline $\begin{array}{l}\text { Suspicion of } \\
\text { mastocytosis } n=5\end{array}$ & 0 & $3 / 1.3 \%$ & $2 / 0.6 \%$ \\
\hline
\end{tabular}

This article is protected by copyright. All rights reserved 
Other $^{\mathrm{a}} \mathrm{n}=13$

0

$4 / 1.7 \%$

$9 / 2.9 \%$

EoE=eosinophilic esophagitis; GORD=gastro-oesophageal reflux disease;

$\mathrm{IBD}=$ inflammatory bowel disease; $\mathrm{IQR}=$ interquartile range

aincludes single patients with diverse indications

This article is protected by copyright. All rights reserved 


\section{Table 2}

Data on endoscopy findings in the study cohort of 666 paediatric patients younger than seven years (y) of age (median age 3.5 y IQR 1.5 -5.2 y) who underwent oesophagogastroduodenoscopy (OGD) because of unspecific gastrointestinal or common respiratory symptoms. Single centre data from years 2006 -2016.

\begin{tabular}{|l|l|l|}
\hline Patient group & $\begin{array}{l}\text { Number of patients with } \\
\text { positive macroscopic } \\
\text { findings (\%) }\end{array}$ & $\begin{array}{l}\text { Number of patients with } \\
\text { positive histological } \\
\text { findings (\%) }\end{array}$ \\
\hline $\begin{array}{l}\text { All 0-6 } \\
\mathrm{n}=666\end{array}$ & $40 / 666(6.0 \%)$ & $72 / 644^{\mathrm{a}}(11.2 \%)$ \\
\hline $\begin{array}{l}\text { Up to 1 y } \\
(\mathrm{n}=122)\end{array}$ & $6 / 122(4.9 \%)$ & $8 / 104(7.7 \%)$ \\
\hline $1-2$ y $(\mathrm{n}=230)$ & $13 / 230(5.7 \%)$ & $28 / 229(12.2 \%)$ \\
\hline $3-6$ y $(\mathrm{n}=314)$ & $21 / 314(6.7 \%)$ & $36 / 311(11.5 \%)$ \\
\hline
\end{tabular}

22 patients without routine biopsies, only macroscopic evaluation available (18 patients in the $0-1 y$ group, one in the group 1-3y and three in the group 3-6y) 
Table 3

Data on the relationship between indications and positive upper endoscopy findings in the study cohort of 666 paediatric patients younger than seven years (y) of age (median age $3.5 \mathrm{y}$, IQR 1.5-5.2) who underwent oesophagogastroduodenoscopy (OGD) because of unspecific gastrointestinal or common respiratory symptoms. Single centre data from years 2006-2016. The histological diagnosis was available for 644 patients $(96.7 \%)$.

\begin{tabular}{|c|c|c|}
\hline Indication & $\begin{array}{l}\text { Number (n) of patients with positive } \\
\text { macroscopic findings }(\%)\end{array}$ & $\begin{array}{l}\text { Number }(\mathrm{n}) \text { of patients with } \\
\text { positive histological findings } \\
(\%)\end{array}$ \\
\hline $\begin{array}{l}\text { Suspicion of GORD } \\
\mathrm{n}=268 \\
\text { median age } 2.8 \mathrm{y} \\
\text { (IQR 1.3-4.9) }\end{array}$ & $\begin{array}{l}\mathrm{n}=11 / 268(4.1 \%) \\
\text { median age } 4.3 \text { y (IQR 2.7-5.7) }\end{array}$ & $\begin{array}{l}\mathrm{n}=44 / 264^{\mathrm{a}}(16.7 \%) \\
\text { median age } 3.7 \text { y (IQR 2-5.8) }\end{array}$ \\
\hline $\begin{array}{l}\text { Common respiratory } \\
\text { symptoms } n=120 \\
\text { median age } 3.5 \mathrm{y} \\
\text { (IQR 1.8-5.2) }\end{array}$ & $\mathrm{n}=1 / 120(0.7 \%)$ & $\begin{array}{l}\mathrm{n}=8 / 115^{\mathrm{b}}(7.0 \%) \\
\text { median age } 3.2 \text { y (IQR } 1.7-5.8)\end{array}$ \\
\hline $\begin{array}{l}\text { Suspicion of IBD } \mathrm{n}=107 \\
\text { median age } 3.6 \mathrm{y} \\
(\mathrm{IQR} 1.9-5.3)\end{array}$ & $\begin{array}{l}\mathrm{n}=6 / 107(5.6 \%) \\
\text { median age 5.1 y (IQR 4.3-5.8) }\end{array}$ & $\begin{array}{l}\mathrm{n}=27 / 107(25.2 \%) \\
\text { median age } 4.3 \text { y (IQR 3.4-5.7) }\end{array}$ \\
\hline $\begin{array}{l}\text { Hematochezia (non- } \\
\text { IBD) } \mathrm{n}=50 \\
\text { median age } 3.5 \mathrm{y} \\
\text { (IQR } 1.7-5.3 \text { ) }\end{array}$ & $\mathrm{n}=2 / 50(4 \%)$ & $\begin{array}{l}\mathrm{n}=11 / 47^{\mathrm{c}}(23.4 \%) \\
\text { median age } 3.5 \mathrm{y}(\mathrm{IQR} 3.1-4.8)\end{array}$ \\
\hline $\begin{array}{l}\text { Exclusion of anatomic } \\
\text { abnormality }{ }^{\mathrm{d}} \mathrm{n}=33 \\
\text { median age } 0.3 \mathrm{y} \\
\text { (IQR 0.06-1.4) }\end{array}$ & $\mathrm{n}=2 / 33(6.0 \%)$ & $\mathrm{n}=1 / 24^{\mathrm{e}}(4.2 \%)$ \\
\hline $\begin{array}{l}\text { Dysphagia } n=16 \\
\text { median age } 4.1 \mathrm{y} \\
(\text { IQR 2.7-5.9) }\end{array}$ & $\mathrm{n}=2 / 16(12.5 \%)$ & $\mathrm{n}=1 / 16(6.3 \%)$ \\
\hline Failure to thrive $n=15$ & $\mathrm{n}=0$ & $\mathrm{n}=1 / 14^{\mathrm{f}}(7.1 \%)$ \\
\hline
\end{tabular}




\begin{tabular}{|c|c|c|}
\hline $\begin{array}{l}\text { median age } 1.2 \mathrm{y} \\
\text { (IQR 0.6-1.8) }\end{array}$ & & \\
\hline $\begin{array}{l}\text { Anemia } \mathrm{n}=8 \\
\text { median age } 4 \mathrm{y} \\
(\mathrm{IQR} 2.2-5.7)\end{array}$ & $\mathrm{n}=0$ & $\mathrm{n}=2 / 8(25 \%)$ \\
\hline $\begin{array}{l}\text { Malabsorption/diarrhea } \\
n=8\end{array}$ & $\mathrm{n}=1 / 8(13 \%)$ & $\mathrm{n}=2 / 8(25 \%)$ \\
\hline $\begin{array}{l}\text { Recurrent abdominal } \\
\text { pain } n=7 \text { median age } \\
5.0 \text { y (IQR 3-6.5) }\end{array}$ & $\mathrm{n}=0$ & $\mathrm{n}=0$ \\
\hline Suspicion of EoE $n=7$ & $\mathrm{n}=1 / 7(14.3 \%)$ & $\mathrm{n}=1 / 7(14.3 \%)$ \\
\hline $\begin{array}{l}\text { Protein-losing } \\
\text { enteropathy } n=5\end{array}$ & $\mathrm{n}=2 / 5(40 \%)$ & $\mathrm{n}=2 / 5(40 \%)$ \\
\hline $\begin{array}{l}\text { Suspicion of } \\
\text { mastocytosis } n=5 \\
\text { median age } 2 \text { y } \\
\text { (IQR 1.3-4.8) }\end{array}$ & $\mathrm{n}=0$ & $\mathrm{n}=0$ \\
\hline $\begin{array}{l}\text { Other }^{\mathrm{g}} \mathrm{n}=13 \\
\text { median age } 4.2 \mathrm{y} \\
(\text { IQR } 1.8-5.6)\end{array}$ & $\mathrm{n}=4 / 13(30.8 \%)$ & $\mathrm{n}=9 / 13(69.2 \%)$ \\
\hline
\end{tabular}

EoE=eosinophilic esophagitis; GORD=gastro-oesophageal reflux disease; IBD=inflammatory bowel disease; $\mathrm{IQR}=$ interquartile range

${ }^{a}$ four patients without histological evaluation ${ }^{b}$ five patients without histological evaluation

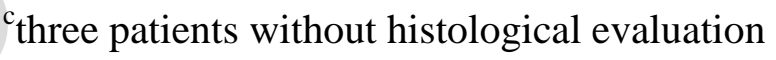
${ }^{\mathrm{d}}$ Patients with malformations of upper airway, head and neck area or the gastrointestinal tract excluded in the patient selection and are not included in this study

enine patients without histological evaluation fone patient without histological evaluation $\mathrm{g}_{\text {includes single patients with diverse indications }}$ 
Table 4

Summary of histological diagnoses obtained from children younger than seven years of age ( $\mathrm{n}=644$ ) during upper endoscopy (oesophagogastroduodenoscopy, OGD) ${ }^{\mathrm{a}}$. Endoscopies included routine biopsies from the duodenum, the corpus, the antrum and the esophagus. Single centre data from years 2006-2016.

\section{a)Oesophagitis}

\begin{tabular}{|c|c|c|}
\hline Histological diagnosis & Number (n, \%) & $\begin{array}{l}\text { Macroscopic appearance } \\
\text { abnormal (n, \%) }\end{array}$ \\
\hline $\begin{array}{l}\text { Mild oesophagitis } \\
\text { Up to 1year } \\
1-2 \text { years } \\
\text { 3-6 years }\end{array}$ & $\begin{array}{l}n=43 / 644(6.7 \%) \\
n=2 \\
n=17 \\
n=24\end{array}$ & $n=4$ \\
\hline $\begin{array}{l}\text { Moderate oesophagitis } \\
\text { Up to } 1 \text { year } \\
1-2 \text { years } \\
\text { 3-6 years }\end{array}$ & $\begin{array}{l}\mathrm{n}=9 / 644(1.4 \%) \\
\mathrm{n}=0 \\
\mathrm{n}=4 \\
\mathrm{n}=5\end{array}$ & $n=4$ \\
\hline Erosive/severe oesophagitis & $n=0$ & $n=0$ \\
\hline $\begin{array}{l}\text { Eosinophilic oesophagitis } \\
\text { Up to } 1 \text { year } \\
1-2 \text { years } \\
3-6 \text { years }\end{array}$ & $\begin{array}{l}n=2 / 644(0.3 \%) \\
n=0 \\
n=1 \\
n=1\end{array}$ & $n=1$ \\
\hline $\begin{array}{l}\text { Candida albicans } \\
\text { oesophagitis }\end{array}$ & $\begin{array}{l}\mathrm{n}=1 / 644(0.2 \%) \\
\text { (age } 6.4 \text { years) }\end{array}$ & $n=1$ \\
\hline $\begin{array}{l}\text { Mild oesophagitis and mild } \\
\text { gastritis }\end{array}$ & $\mathrm{n}=2 / 644(0.3 \%)$ & $n=0$ \\
\hline $\begin{array}{l}\text { Moderate oesophagitis and } \\
\text { mild gastritis } \\
\text { Up to } 1 \text { year } \\
\text { 1-2 years } \\
\text { 3-6 years }\end{array}$ & $\begin{array}{l}n=3 / 644(0.3 \%) \\
n=1 \\
n=1 \\
n=1\end{array}$ & $n=1$ \\
\hline
\end{tabular}

This article is protected by copyright. All rights reserved 
\begin{tabular}{|l|l|l|} 
Gastric metaplasia & $\begin{array}{l}\mathrm{n}=1 / 644(0.2 \%) \\
\text { (age 1.7 years) }\end{array}$ & $\mathrm{n}=1$ \\
\hline
\end{tabular}

${ }^{\mathrm{a}}$ The total number of patients was 666 (22 patients without routine biopsies: 18 patients in the up to $1 \mathrm{y}$ group, one in the group $1-2 \mathrm{y}$ and three in the group 3-6y)

This article is protected by copyright. All rights reserved 


\section{b)Gastritis}

\begin{tabular}{|c|c|c|}
\hline Histological diagnosis & Number (n, \%) & $\begin{array}{l}\text { Macroscopic appearance } \\
\text { abnormal n (\%) }\end{array}$ \\
\hline $\begin{array}{l}\text { Mild/superficial gastritis } \\
\text { Up to } 1 \text { year } \\
1-2 \text { years } \\
\text { 3-6 years }\end{array}$ & $\begin{array}{l}n=12 / 644^{a}(1.9 \%) \\
n=3 \\
n=2 \\
n=7\end{array}$ & $\mathrm{n}=0$ \\
\hline $\begin{array}{l}\text { Gastritis associated with } \\
\text { concurrently diagnosed } \\
\text { inflammatory bowel disease } \\
\text { Up to } 1 \text { year } \\
1-2 \text { years } \\
\text { 3-6 years }\end{array}$ & $\begin{array}{l}n=13 / 644(2.0 \%) \\
n=0 \\
n=2 \\
n=11\end{array}$ & $n=1$ \\
\hline $\begin{array}{l}\text { Moderate gastritis } \\
\text { Up to } 1 \text { year } \\
\text { 1-2 years } \\
\text { 3-6 years }\end{array}$ & $\begin{array}{l}n=2 / 644(0.3 \%) \\
n=0 \\
n=0 \\
n=2\end{array}$ & $\mathrm{n}=1$ \\
\hline $\begin{array}{l}\text { Eosinophilic gastritis } \\
\text { Up to } 1 \text { year } \\
1-2 \text { years } \\
\text { 3-6 years }\end{array}$ & $\begin{array}{l}n=2 / 644(0.3 \%) \\
n=0 \\
n=0 \\
n=2\end{array}$ & $\mathrm{n}=0$ \\
\hline $\begin{array}{l}\text { Collagenous gastritis } \\
\text { Up to } 1 \text { year } \\
1-2 \text { years } \\
\text { 3-6 years }\end{array}$ & $\begin{array}{l}n=1 / 644(0.2 \%) \\
n=0 \\
n=0 \\
n=1 \text { (age } 5.8 \text { years) }\end{array}$ & $\mathrm{n}=1$ \\
\hline
\end{tabular}

${ }^{\mathrm{a}}$ The total number of patients was 666 (22 patients without routine biopsies: 18 patients in the up to $1 \mathrm{y}$ group, one in the group 1-2y and three in the group 3-6y) 


\section{c)Duodenitis}

\begin{tabular}{|c|c|c|}
\hline Histological diagnosis & Number (n, \%) & $\begin{array}{l}\text { Macroscopic appearance } \\
\text { abnormal n (\%) }\end{array}$ \\
\hline $\begin{array}{l}\text { Duodenitis with concurrent } \\
\text { oesophagitis } \\
\text { Up to } 1 \text { year } \\
1-2 \text { years } \\
\text { 3-6 years }\end{array}$ & $\begin{array}{l}n=1 / 644^{\mathrm{a}}(0.2 \%) \\
\mathrm{n}=1 \text { (age } 0.8 \text { years }) \\
\mathrm{n}=0 \\
\mathrm{n}=0\end{array}$ & $n=0$ \\
\hline $\begin{array}{l}\text { Severe duodenitis with severe } \\
\text { gastritis } \\
\text { Up to } 1 \text { year } \\
1-2 \text { years } \\
\text { 3-6 years }\end{array}$ & $\begin{array}{l}n=1 / 644(0.2 \%) \\
n=1(\text { age } 0.2 \text { years }) \\
n=0 \\
n=0\end{array}$ & $n=1$ \\
\hline $\begin{array}{l}\text { Eosinophilic enteritis } \\
\text { including eosinophilic } \\
\text { oesophagitis, gastritis and } \\
\text { duodenitis } \\
\text { Up to } 1 \text { year } \\
1-2 \text { years } \\
\text { 3-6 years }\end{array}$ & $\begin{array}{l}n=1 / 644(0.2 \%) \\
n=0 \\
n=1 \text { (age } 2.4 \text { years) } \\
n=0\end{array}$ & $n=1$ \\
\hline
\end{tabular}

${ }^{\mathrm{a}}$ The total number of patients was 666 (22 patients without routine biopsies: 18 patients in the up to $1 \mathrm{y}$ group, one in the group 1-2y and three in the group 3-6y) 


\section{apa_15027_f1.pdf}

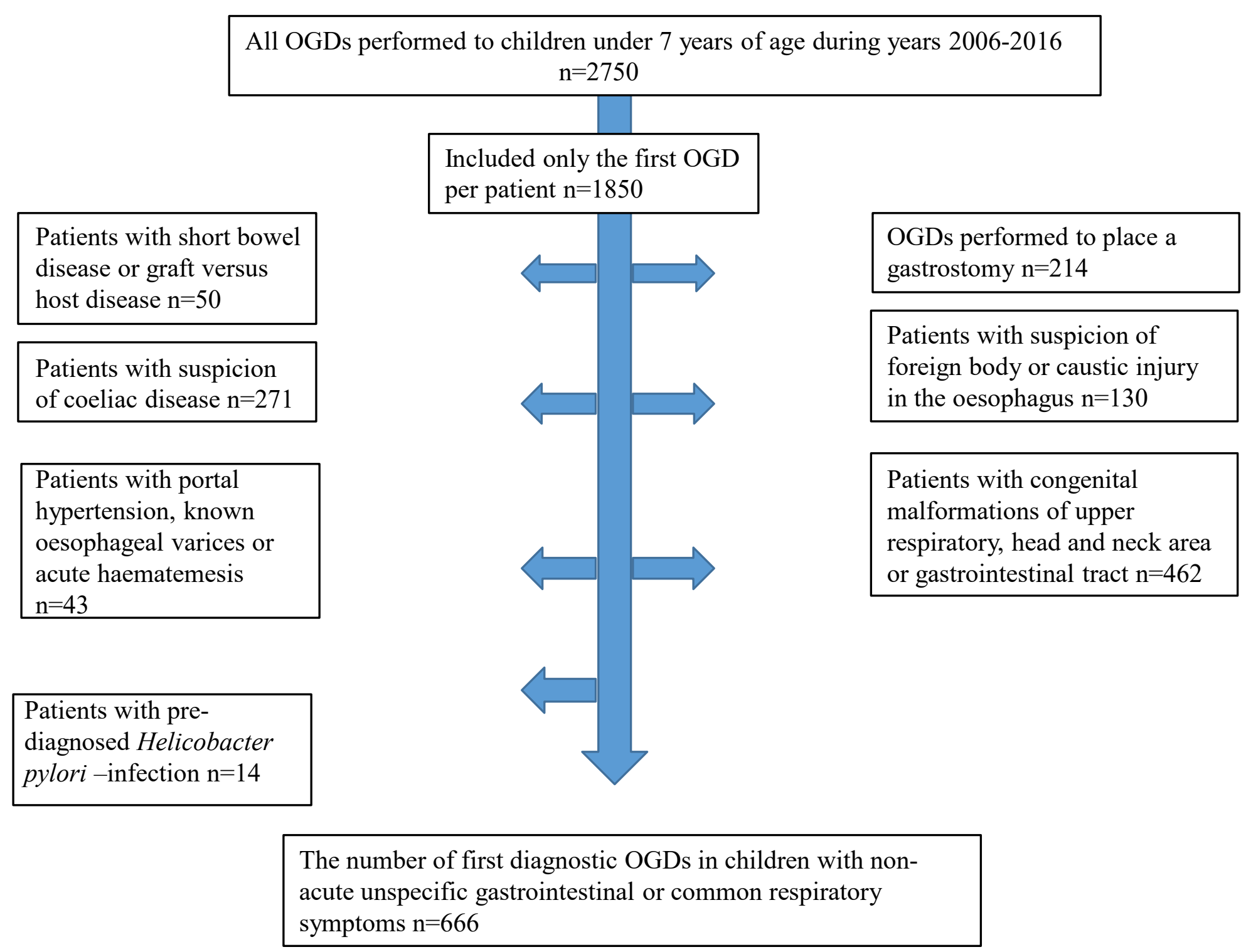

This article is protected by copyright. All rights reserved 
Figure 2

Data on number of oesophagogastroduodenoscopy (OGD) in a single tertiary level children's hospital during years 2006-2016.

The number of OGDs in children younger than seven years of age

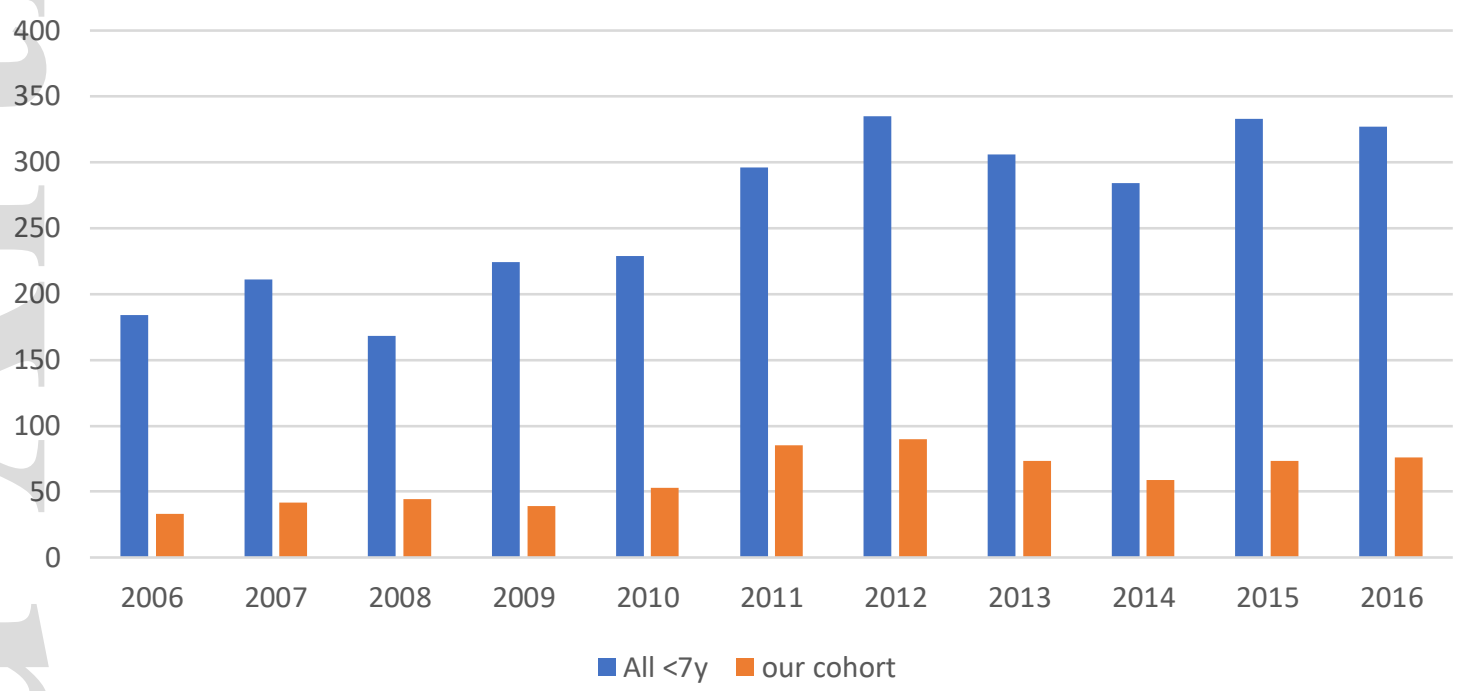

This article is protected by copyright. All rights reserved 